\title{
SPEAKING ABOUT THE PAST FROM DIFFERENT PERSPECTIVES: THE ACQUISITION OF ITALIAN L2 BY NORWEGIAN AND RUSSIAN LEARNERS
}

\author{
ELIZAVETA KHACHATURYAN \\ University of Oslo
}

\section{A BS TRACT}

This study investigates the influence of L1 language-specific patterns on the acquisition of L2 structures. The lack of certain grammatical categories is often compensated for at another level of linguistic structure. This study analyses how Italian past tenses (connected with the category of aspect) are acquired by Russian and Norwegian learners. In Norwegian, in contrast to Russian and Italian, there is no grammatical aspect.

The data analyzed contain a written narration of a short story presented through four pictures and were collected from several groups of informants: Russian and Norwegian native speakers, learners of Italian (levels B1 and C1), and Italian native speakers (the control group).

The results obtained show that Norwegian learners, independently of their level, use more temporal connectors in their narratives. However, verbal semantics or temporal connectors (usually considered to be triggers of Italian past tenses) do not help them use the correct form. Russian learners performed better on the test. Their errors show that the textual function of the verb is more important for them than its semantics. However, they overuse coordinative connectors ( $e$ 'and' and $m a$ 'but') at the beginning of sentences. These results lead to further discussion of textual features in the three languages and the role of the tense-aspect category in text structure.

\section{INTRODUCTION}

In recent decades, many studies have been dedicated to the influence of linguistic structures on the way people think and speak (e.g., Pavlenko 2011; Slobin 1991). Differences in verbal structure are among the topics most often discussed (e.g., Bylund 2011; Schmiedtová, von Stutterheim \& Carroll 2011). Previous studies have taken into account various groups of speakers (native speakers of one language, bilinguals, or learners of an L2) and various language combinations, with the data usually containing narratives obtained in various ways (e.g., Verhoeven \& Strömqvist 2001). 
One of the main problems discussed in these studies is how speakers of various languages describe what they see differently because of the different grammatical options the language offers them-or, in other words, how a lack of linguistic means at one level (e.g., certain grammatical categories) is compensated for at another level of linguistic structure. In this context, the analysis of the tense-aspect category, which involves different levels of language structure, appears to be a particularly interesting and overarching question.

The focus of this paper is the influence of the L1's language-specific patterns on the acquisition of L2 structures. If the text structure changes depending on the presence or lack of an aspect category in the language (as shown in several studies based on monolingual and bilingual data; e.g., Bylund 2011; Schmiedtová, von Stutterheim \& Carroll 2011), in which way does a text produced in L2 show the influence of L1? This study analyzes data from two groups of students learning Italian: one group is native speakers of Russian, and the other group is native speakers of Norwegian. Each of these three languages has a different tense-aspect system, especially for past forms.

[1] THEORETICAL BACKGROUND: THE ROLE OF TENSE AND ASPECT IN TEXT STRUCTURE

The markedness of aspect in a language affects the entire phrase structure and the connection between phrases. This has been shown, first of all, in studies on monolingual speakers (Bylund 2011): in tests containing a picture description in the present, speakers of languages that have an aspectual system, in particular languages that mark verbs "for imperfective (or progressive) aspect on a productive and obligatory scale" (such as Arabic, English, Russian, and Spanish) "pay little attention to endpoints both verbally and visually" (e.g. 'a man is riding'), "and resort to deictic linking strategies when sequencing events" in the present (e.g., He is slowly waking up. He looks in front of him. And there is a big rock coming down) (Bylund 2011: 112). On the other hand, speakers of languages in which aspect "does not constitute a grammatical category, [and] the use of lexical constructions to express ongoingness is not compulsory" (e.g. Dutch, German, Norwegian, and Swedish), "refer to and attend to event endpoints (e.g. 'a man is riding to a village'). Moreover, this group of speakers links event sequences anaphorically and is more oriented toward holistic event perspectives (e.g. The man gets up from the ground. And then he looks around. And then a stone falls down)" (Bylund 2011: 113). These findings were later confirmed in an analysis of Spanish and Swedish monolinguals compared with bilinguals with the same language combination (e.g., Bylund \& Jarvis 2011).

In the analysis of narratives (about past events) produced by bilingual SwedishFrench children, temporal connectors used in Swedish seem to compensate for the lack of the aspect category: "As for Swedish, tense or aspect is, apparently, 
not essential as a text-structuring device. In studies of stories told by Swedish children, temporal connectors seem to play an important role for structuring the story" (Viberg 1991: 1064, cited in Schlyter 1996; similar observations for SpanishSwedish bilinguals are found in Bylund 2011).

Can it then be supposed that Norwegian learners of Italian will prioritize or overuse temporal connectors when they are uncertain about the use of the past verb form? To answer to this question, I chose two groups of Norwegian informants at two different levels (less proficient = level B1 and more proficient = level C1; see below for a more detailed description).

[2] A BRIEF OVERVIEW OF PAST TENSES SYSTEM IN THE THREE LANGUAGES

The analysis focuses on three languages that have different status for my informants: Norwegian and Russian are their native languages, and Italian is the acquired language for both groups. These languages belong to three different language groups (Germanic, Slavic, and Romance) and are characterized by important differences in their verbal grammar. The differences in the system of past tenses are briefly summarized in Table 1 .

TABLE 1: Past tenses in three languages (Italian, Norwegian, and Russian)

\begin{tabular}{llll}
\hline & Italian & Norwegian & Russian \\
\hline Simple tenses & $\begin{array}{l}\text { Passato remoto } \\
\text { Imperfetto }\end{array}$ & Preteritum & $\begin{array}{l}\text { Past tense of } \\
\text { perfective/im- } \\
\text { perfective verbs }\end{array}$ \\
$\begin{array}{l}\text { Compound tenses } \\
\text { (with an auxiliary }\end{array}$ & $\begin{array}{l}\text { Passato prossimo } \\
\text { Trapassato prossimo } \\
\text { (Trapassato remoto) }\end{array}$ & $\begin{array}{l}\text { Perfectum } \\
\text { Plusquamperfectum }\end{array}$ & \\
\hline
\end{tabular}

Italian and Norwegian have a well-developed system of past tenses (see Table 1), including simple and compound tenses, as well as a past tense related to another event in the past: the pluperfect. Russian has only one past tense, but it can describe the action differently depending on the aspect of the verb. All Russian verbs belong to either the perfective or imperfective aspect. In Italian, the perfective (pf)/imperfective (impf) distinction is traditionally described as being encoded in the past tenses passato prossimo (pf) and imperfetto (impf) (e.g., Bertinetto 1997), but at the same time it is closely connected to the verbal semantics (the property of telicity, for example, that is basically encoded in the syntax-semantics of the direct objects). In Norwegian there is no grammatical aspect (Faarlund, Lie \& Vannebo 1997), but there are some syntactic constructions that in some cases can be used to describe aspectual differences; for example, periphrastic constructions or repetition of the verb. 
The main focus of the test proposed to the informants was to explore how they distinguish the functions of two Italian past tenses (imperfetto IMP and passato prossimo PPR) when constructing a text in Italian, which criteria of choice are important for them, and what other means they use in their narrative.

\section{[3] MATERIAL ANALYZED}

The material used for this study contains experimental data collected for three groups of Italian L2 informants (+ a control group of Italian native speakers). Two groups were Norwegian native speakers studying Italian at two different levels: $\mathrm{B} 1$ and $\mathrm{C} 1$. Tests were taken after each group finished the course at level B1 or C1 at the University of Oslo. The third group comprised Russian learners of Italian (from the Russian State University for the Humanities) taking the course at level B1. The test contained four pictures representing a short story about two chicks that, while looking for worms in the garden, find something long that at the beginning seems to be a worm, but turns out to be a mouse's tail. The students were asked to describe (in written form) what happened in the pictures. They were also given a list of vocabulary with some words that they might not know. The time was not strictly limited, but the entire test did not last more than twenty minutes.

\section{[4] ANALYSIS AND DISCUSSION}

The results of the analysis can be discussed from quantitative and qualitative points of view as presented in the following tables.

\section{[4.1] General overview}

As shown in Table 2, the narratives by Russian students are the shortest, whereas the more proficient Norwegian students (level C1) used the greatest number of words. The control group, in spite of the large number of words (but still fewer than Norwegian C1 students), built fewer sentences in which they used fewer finite forms (72.13\%) compared to other groups of informants. This observation confirms the main tendency that characterizes Italian as a language with a high degree of subordination (also described in Korzen 2007). Intersegmental connectors prevail in the control group's description. Norwegian students at level C1 also use quite a large number of connectors. The inclination toward temporal connectors in Norwegian native speakers that emerged from this experiment should be checked with a larger number of informants. Nonetheless, this observation also confirms the data collected with bilingual Swedish-French children (Viberg 1991) and with Spanish-Swedish bilinguals (Bylund 2011): both studies discuss the importance of temporal connectors for text-structuring in Swedish.

Interestingly, Russian informants, although they use few connectors, often start sentences with the coordinative connectors $e$ ('and') and $m a$ ('but'). This 
fact should be also checked further with a larger group of informants.

TABLE 2: General information about the narratives collected

\begin{tabular}{lllllll}
\hline & $\begin{array}{l}\text { Mean } \\
\text { num- } \\
\text { ber of } \\
\text { words }\end{array}$ & $\begin{array}{l}\text { Mean } \\
\text { num- } \\
\text { ber } \\
\text { of sen- } \\
\text { tences }\end{array}$ & $\begin{array}{l}\text { Mean } \\
\text { number } \\
\text { of verbal } \\
\text { forms } \\
\text { / finite } \\
\text { forms }^{1}\end{array}$ & $\begin{array}{l}\text { Mean } \\
\text { number } \\
\text { of connec- } \\
\text { tors }\end{array}$ & $\begin{array}{l}\text { Mean number } \\
\text { of coordinative } \\
\text { connectors at } \\
\text { the beginning } \\
\text { of the sentence: } \\
\text { ma, } e\end{array}$ & $\begin{array}{l}\text { Mean } \\
\text { temporal } \\
\text { connec- } \\
\text { tors }\end{array}$ \\
\hline B1 & 73.45 & 6.45 & $\begin{array}{l}14.1 / 11.9 \\
(84.4 \%)\end{array}$ & 3.7 & 0.3 & 2.1 \\
C1 & 92.4 & 7 & $\begin{array}{l}16 / 12.6 \\
(78.75 \%)\end{array}$ & 5.22 & 0.55 & 3.6 \\
B1 & 68 & 6 & $\begin{array}{l}13 / 10.5 \\
(79.8 \%)\end{array}$ & 4.9 & 1.3 & 2 \\
$\begin{array}{l}\text { Rus } \\
\text { Control } \\
\text { group }\end{array}$ & 85.25 & 5.25 & $\begin{array}{l}15.25 / 11 \\
(72.13 \%)\end{array}$ & 6.5 & 0.5 & 3 \\
\hline
\end{tabular}

\section{[4.2] Analysis of errors}

Table 3 presents the quantitative analysis of errors.

TABLE 3: Quantitative analysis

\begin{tabular}{llll}
\hline & B1 (L1 Norwegian) & C1 (L1 Norwegian) & B1 (L1 Russian) \\
\hline PPR instead of IMP & 1.39 & 0.22 & 0.49 \\
IMP instead of PPR & 0.4 & 1.3 & 0 \\
\hline
\end{tabular}

As can be seen from Table 3, Russian students never used the IMP instead of the PPR. There were also very few errors in erroneous use of the PPR instead of the IMP. In the narratives produced by the Norwegian students, the PPR prevailed. There are some individual preferences in this use: for example, three students in the Norwegian B1 group used only the PPR to describe what was happening in the pictures. One student in the Norwegian C1 group overused the IMP (sixteen verbal forms out of twenty-four verbal finite forms), and the use of ten forms (out of sixteen) was erroneous. The most frequent error by Norwegian learners was the use of stative verbs (essere 'to be', assomigliare 'to look like') in the PPR. The

[1] The percentage is given for the number of finite forms compared to non-finite verbal forms, and shows an important tendency toward subordination in the Italian text (observed in, e.g., Korzen 2007). 
explanation may be that the Norwegian students do not see the textual function associated with each verbal form (as proposed by, e.g., Bardovi-Harlig 1998, 2012 for L2 acquisition). The most frequent error by Russian students is a tendency to mark the beginning of an action with the PPR independently of the verbal type (e.g., *Due pulcini hanno avuto fame 'Two chicks have been hungry'). This error can be explained by another vision of the verbal forms in the text: the textual function seems to be more important for the Russian native speakers than the verbal semantics. The overuse of the coordinative connectors can be seen as another confirmation of this vision.

CONCLUDING REMARKS

This study focused on the influence of the L1's language-specific patterns on the acquisition of L2 structures. It has been seen that the typology of mistakes changes for Russian and Norwegian learners of Italian, but the text structure also shows some differences in the groups analyzed.

The narrations by Norwegian learners have two characteristics: a large share of errors in the use of past tenses, which shows that the difference between the IMP and the PPR is not completely acquired, and several temporal connectors. In particular, the less-proficient learners (level B1) used fewer connectors than the more proficient learners $(\mathrm{C} 1)$, whereas the more proficient Norwegian learners (C1) used more temporal connectors in their narration than even the Italian native speakers in the control group. This prevalence of temporal connectors can be seen as a kind of compensation: the other linguistic means play the role of elements that are not presented or completely acquired in the language. If Norwegian learners often do not see the difference between the IMP and the PPR (which is shown by errors in their narration), they tend to find another way to create a coherent text: instead of distinguishing between two tenses, they use temporal connectors that can help mark different types of relations between the actions. If the learner's L1 influences the acquisition of L2, can one then say that temporal connectors prevail in a Norwegian text compared to an Italian text? This question could be the focus of future research.

Another interesting observation concerns Russian learners of Italian: they make very few errors in the use of past tenses, but they overuse coordinative connectors ( $m a$ 'but' and $e$ 'and') at the beginning of sentences. On the one hand, this use can be explained by the lack of lexical means in Russian students' vocabulary at level B1: they try to create a text but do not have enough words to do so. On the other hand, the overuse of the coordinative connectors can be interpreted as an attempt to create a text in which all of the elements-the use of verbal forms together with connectors-serve that purpose. In any case, this overuse may lead to a more detailed analysis of coordinative connectors' role in Russian and Italian texts. 


\section{REFERENCES}

Bardovi-Harlig, K. 1998. Narrative structure and lexical aspect: conspiring factors in second language acquisition of tense-aspect morphology. Studies in Second Language Acquisition 20(4). 471-508.

Bardovi-Harlig, K. 2012. Second language acquisition. In R. Binnick (ed.), Handbook of tense and aspect, 481-503. Oxford: Oxford University Press.

Bertinetto, P. M. 1997. Il dominio tempo-aspettuale. demarcazioni, intersezioni, contrasti. Turin: Rosenberg \& Sellier.

Bylund, E. 2011. Language-specific patterns in event conceptualization: insights from bilingualism. In A. Pavlenko (ed.), Thinking and speaking in two languages, 108-142. Bristol: Multilingual Matters.

Bylund, E. \& S. Jarvis. 2011. L2 effects on 11 event conceptualization. Bilingualism: Language and Cognition 14(1). 47-59.

Faarlund, J. T., S. Lie \& K. I. Vannebo. 1997. Norsk referansegrammatikk. Universitetsforlag.

Korzen, I. 2007. Mr. Bean e la linguistica testuale. Considerazioni tipologico-comparative sulle lingue romanze e germaniche. In M. Barbera, E. Corino \& C. Onesti (eds.), Corpora e linguistica in rete, 209-224. Perugia: Guerra edizioni.

Pavlenko, A. (ed.). 2011. Thinking and speaking in two languages. Bristol: Multilingual Matters.

Schlyter, S. 1996. Bilingual children's stories: french passé compose / imparfait and their correspondences in swedish. Linguistics 34. 1059-1085.

Schmiedtová, B., C. von Stutterheim \& M. Carroll. 2011. Language-specific patterns in event construal of advanced second language speakers. In A. Pavlenko (ed.), Thinking and speaking in two languages, 66-107. Bristol: Multilingual Matters.

Slobin, D. 1991. Learning to think for speaking: native language, cognition, and rhetorical style. Pragmatics 1. 7-25.

Verhoeven, L. \& S. Strömqvist (eds.). 2001. Narrative development in a multilingual context. Amsterdam: Benjamins.

Viberg, Å. 1991. Utvärdering av skolförberedelsegrupper i rinkeby. report 4, en longitudinell djupstudie av språkutvecklingen. Stockholm: Rinkeby Stadsdelsförvaltning \& Centrum för Tvårspråklighetsforskning.

AUTHOR CONTACT INFORMATION

Elizaveta Khachaturyan

University of Oslo

elizaveta.khachaturyan@ilos.uio.no 